\title{
PENGELOLAAN BANTUAN KEUANGAN BERSIFAT KHUSUS DARI PEMERINTAH KABUPATEN DALAM ANGGARAN PENDAPATAN DAN BELANJA DESA
}

\author{
Johan Satriajaya \\ Lilik Handajani \\ I Nyoman Nugraha Ardana Putra \\ Universitas Mataram \\ ipe.jaya@gmail.com
}

\begin{abstract}
This research aimed to analyse the specially-allocated financial aid policy from district government to village government of Samanta. The fact indicates that there has been a misconduct in budget management, which becomes the main reason to do this research. This research employs a qualitative method, using the phenomenological-hermeneutic approach. Data collection uses an in-depth interview with village financial manager, and supported by observation and documentation. Data analysis applies the method of phenomenological-hermeneutic perspectives. The result shows that specially-allocated financial aid management was not appropriately implemented. This was caused by the inconsistency of local government in implementing its local regulation. District government is using its power discretion and the regulation discretion. High tendency of different interests in implementing the policy has led to a pseudo-statement to empower village government and village society. Thus, it needs better commitment from district government to set aside the interests of certain groups and politics to ensure that the main objective of that policy could be implemented properly.
\end{abstract}

Keywords:

policy; financial assistance; district government; village financial

Implementasi Undang-undang Nomor 6 Tahun 2014 tentang Desa selanjutnya disebut UU No. 6/2014 bertujuan untuk mengembangkan, melindungi dan memberdayakan desa agar menjadi kuat, maju, mandiri, dan demokratis sehingga dapat menciptakan landasan yang kuat dalam melaksanakan pemerintahan dan pembangunan menuju masyarakat yang adil, makmur, dan sejahtera. Regulasi ini menempatkan pemerintahan di desa sebagai pemerintahan masyarakat, hybrid antara self governing community dan local self government(Sutoro, 2015). Semangat dan tujuan pembangunan desa yang diamanatkan UU No. 6/2014, ditetapkan sebagai salah satu prioritas pembangunan nasional sebagaimana dinyatakan dalam Peraturan Presiden Nomor 2 Tahun 2015 tentang Rencana Pembangunan Jangka Menengah Nasional Tahun 2015-2019.

Regulasi desa ini menjadi sebuah harapan, agar desa dengan segala kewenangannya dapat lebih aktif dan kreatif dalam pembangunan desa. Salah satu tugas yang merupakan kewenangan desa adalah mengelola keuangan secara mandiri. Besarnya anggaran yang dikelola oleh pemerintah desa saat ini merupakan salah satu implikasi dari terimplementasinya UU No. 6/2014. Peningkatan jumlah transfer Dana Desa yang bersumber dari Anggaran Pendapatan Belanja Negara dari tahun 2015 s/d 2017, menjadikan jumlah transfer Dana Desa yang diterima oleh seluruh desa di Indonesia secara nasional mengalami peningkatan. Peningkatan tersebut diikuti juga oleh jumlah transfer desa yang bersumber dari Anggaran Pendapatan Belanja Daerah tiap kabupaten di Indonesia yang terdiri dari Alokasi Dana Desa dan Bagi Hasil Pajak dan Retribusi Daerah. Selain itu, desa juga menerima bantuan keuangan dari pemerintah provinsi dan pemerintah kabupaten.

Pemerintah telah menetapkan beberapa peraturan pemerintah sebagai pedoman pelaksanaan implementasi UU No. 6/2014. Peraturan pemerintah yang diterbitkan antara lain Peraturan Pemerintah Nomor 43 Tahun 2014 tentang Pedoman Pelaksanaan Undang-undang 
Nomor 6 Tahun 2014 yang telah diubah dalam Peraturan Pemerintah Nomor 47 Tahun 2015 selanjutnya disebut PP No. 47/2015. Peraturan pemerintah tersebut menjadi dasar penetapan Peraturan Menteri Dalam Negeri Nomor 113 Tahun 2014 sebagai Pedoman Pengelolaan Keuangan Desa selanjutnya disebut Permendagri No. 113/2014. Mekanisme yang diatur dalam permendagri tersebut, secara umum mengadopsi mekanisme pengelolaan keuangan pemerintah daerah yang diatur dalam selanjutnya disebut Permendagri No. 13/2006 tentang Pedoman Pengelolaan Keuangan Daerah.

Kebijakan pemerintah yang ditetapkan melalui berbagai regulasi diatas menunjukkan bahwa pemerintah berupaya memberikan pedoman dan petunjuk yang jelas bagi pengelola keuangan desa, agar pengelolaan yang dilaksanakan dapat memberikan hasil yang optimal. Terkait dengan hal itu, IAI-KSAP (2015) menyatakan bahwa pengelolaan keuangan desa sejatinya tidak hanya menyangkut ketersediaan peraturan pendukungnya dan sarana-prasarana, namun yang paling penting adalah adanya sumber daya manusia yang memiliki kompetensi dan komitmen yang handal. Keberhasilan pelaksanaan tugas pemerintahan desa khususnya dalam pengelolaan keuangan desa menurut IAI-KSAP (2015) sangat dipengaruhi oleh tingkat pendidikan aparat desa yang saat ini sebagian besar relatif rendah.

Permendagri No. 113/2014 mengatur bahwa pengelolaan keuangan desa terdiri dari tahapan kegiatan yang meliputi: perencanaan, pelaksanaan, penatausahaan, pelaporan dan pertanggungjawaban. Regulasi ini menjadikan kepala desa memiliki kewenangan dan kekuasaan yang sangat besar dalam mengelola keuangan desa. Oleh karena itu, pengendalian besarnya anggaran dan kewenangan desa mutlak diperlukan agar dana publik tersebut tepat dan baik dalam pengelolaannya karena merupakan discretionary cost (Mardiasmo, 2009).

Dinamika pengelolaan keuangan desa secara nasional termasuk di Kabupaten Samanta, saat ini menunjukkan fenomena serupa dengan adanya berbagai permasalahan, terutama terkait dengan anggaran yang bersumber dari bantuan keuangan pemerintah kabupaten. Selain pemberitaan oleh media, adanya penyimpangan dalam pengelolaan keuangan desa di Kabupaten Samanta juga terlihat dari hasil pemeriksaan reguler Inspektorat Kabupaten Samanta terhadap pengelolaan keuangan desa tahun anggaran 2015. Hasil obeservasi awal, dalam sebuah diskusi dengan seorang Auditor pada Inspektorat Kabupaten Samanta menerangkan bahwa jika dibandingkan dengan hasil pemeriksaan reguler tahun-tahun sebelumnya (dibawah tahun 2014), terjadi peningkatan jumlah dan jenis temuan dalam pengelolaan keuangan desa. Berdasarkan hal tersebut menunjukkan bahwa dalam pengelolaan keuangan desa, jumlah penyimpangan ceteris paribus dengan jumlah anggaran. Sementara itu, BPK-RI dalam opini terhadap laporan keuangan pemerintah Kabupaten Samanta juga menyatakan bahwa pengelolaan dan penatausahaan Dana Desa di Kabupaten Samanta belum optimal. Berbagai temuan dalam LHP Inspektorat Kabupaten Samanta, memperkuat hasil evaluasi KPK-RI (2015), yang menyimpulkan bahwa terdapat kelemahan regulasi dan kelembagaan, tata laksana, pengawasan dan sumber daya manusia.

Berbagai temuan dan rekomendasi dalam Badan Pemeriksa Keuangan Republik Indonesia maupun Inspektorat Kabupaten Samanta menunjukkan bahwa penyebab penyimpangan adalah pengelola keuangan desa yang tidak sepenuhnya mempedomani dan mematuhi ketentuan regulasi. Hal ini menurut Julianto (2012) lumrah terjadi pada lembaga pemerintah karena adanya mental koruptif, politis serta penegakan hukum yang lemah. Sejalan dengan hal itu, maka kapasitas yang dimiliki aparat desa mempengaruhi keberhasilan pengelolaan keuangan desa, khususnya dalam memenuhi prinsip transparant, accountable, dan responsible (Nahruddin, 2014). Kondisi ini berpeluang menimbulkan adanya tindakan personal atau bagian tertentu dalam organisasi yang tidak sesuai atau menyimpang dengan tujuan utama organisasi. Hansen \& Mowen (2007) menyebut hal itu sebagai dysfunctional behavior atau perilaku menyimpang yang dapat merugikan organisasi. Sependapat dengan Griffin \& Lopez (2005) yang menyatakan bahwa jika terdapat bad behavior dalam organisasi akan mempengaruhi kinerja organisasi serta dapat menggagalkan pencapaian tujuan utama organisasi. 
Berbagai penyimpangan oleh pengelola keuangan desa di Kabupaten Samanta yang berada dalam proses hukum pihak berwenang, menjadi indikator bahwa penyimpangan yang dilakukan sudah mengarah pada fraud dan korupsi. Persoalan dalam pengelolaan keuangan desa dipengaruhi oleh faktor internal dan eksternal. Perubahan regulasi dinyatakan oleh Etienne (2010); Pillay \& Ron (2014); Danish, Munir, Kausar, \& Jabbar (2014) mempengaruhi lingkungan kerja, baik internal maupun eksternal. Senada dengan hal tersebut, Ely (2009) juga menyatakan bahwa sebuah regulasi akan mempengaruhi output dan outcome sebuah program. Selain itu, suatu perubahan, terutama regulasi juga memberikan suatu perubahan terhadap kompleksitas pekerjaan atau beban kerja, sehingga akan berpengaruh terhadap perubahan pada berbagai aspek lainnya, baik internal maupun eksternal organisasi (Ke \& Shi, 2014). Oleh karena itu, organisasi membutuhkan kepemimpinan yang baik dalam rangka pencapaian tujuannya, terlebih ketika adanya perubahan yang cukup mendasar. Guo, Dai, \& Yang (2016) dan Alemu (2016) memperkuat hal tersebut dengan menyatakan bahwa terdapat sebuah korelasi positif yang kuat antara efektifitas kepemimpinan (kinerja pimpinan) dengan perilaku organisasi.

Keberhasilan organisasi menjalankan program dalam rangka pencapaian tujuan tidak hanya oleh kepemimpinan yang baik, namun harus didukung ketersediaan staf atau karyawan yang baik pula. Hal ini tegaskan oleh Otterlo 2013); Bagire \& Namada (2013); Fajri, Setyowati, \& Siswidiyanto (2012) yang menyatakan bahwa kemampuan sumber daya manusia sebuah organisasi memiliki efek positif pada kinerja organisasi, karena hal itu mampu menjadikan pengelolaan keuangan dapat efektif, efisien dan ekonomis serta memenuhi unsur transparan dan akuntabel.

(Namada, Aosa, Awino, \& Wainaina, 2014) juga menyatakan bahwa tiap anggota tim dalam sebuah organisasi harus memberikan partisipasi nyata dengan bekerjasama serta melaksanakan tugas dan fungsinya masing-masing. Sejalan dengan Guo et al. (2016) yang menyatakan bahwa sebagai sebuah tim, maka kinerja individu khususnya pemimpin serta hubungan internal didalamnya menjadi komponen penting dari keberhasilan tim tersebut. Selain itu, Bagire \& Namada (2013) juga menyatakan bahwa untuk memastikan keselarasan operasional kinerja organisasi sangat dibutuhkan kombinasi dari keterampilan manajerial; perencanaan strategis; kemampuan keuangan; dan situasi kondisi lingkungan kerja yang kondusif serta adanya partisipasi aktif seluruh tim dalam organisasi.

Berbagai unsur atau elemen hasil kajian empiris terkait dysfunctional behavior belum tersaji secara holistik pada satu kajian empiris. Simpulan hasil kajian menyajikan justifikasi secara parsial antara unsur teknis dengan non teknis. Penyajian hasil dan kesimpulan terhadap unsur yang sama pada dasarnya saling menguatkan, namun belum disajikan secara simultan dan mendalam dalam sebuah kajian. Selain itu, kajian empiris sebelumnya lebih banyak menggunakan pendekatan kuantitatif, sehingga banyak rekomendasi untuk penelitian selanjutnya diarahkan menggunakan pendekatan kualitatif dengan metode analisis dan interpretasi yang lebih mendalam. Hal ini dimaksudkan agar dapat mengungkapkan makna dari perilaku, pengalaman dan pemahaman informan. Berdasarkan hasil kajian empiris sebelumnya, dapat disintesiskan bahwa berbagai elemen yang telah diidentifikasikan sebagai penyebab terjadinya dysfunctional behavior adalah unsur teknis dan non teknis. Unsur non teknis yang menjadi mendominasi terjadinya dysfunctional behavior dalam beberapa kajian adalah perilaku, gaya hidup, spiritualitas, kearifan lokal, kepemimpinan, regulasi serta berbagai perubahan yang dialami individu dan organisasi, sedangkan selebihnya merupakan unsur yang bersifat hal-hal teknis.

Hasil kajian Kusumastuti \& Meiranto (2012); Gul (2015); Efferin (2015) sejalan dengan pendapat Raghunandan, Ramgulam, \& Mohammaded (2012) dan Paino, Ismail, \& Smith (2014) yang menyatakan bahwa aspek non teknis harus diperhitungkan bersama-sama sebagai fokus kajian ilmiah karena saling mempengaruhi dalam pencapaian tujuan organisasi. Fokus kajian empiris diatas didominasi tentang determinan dan implikasi dari dysfuctional behavior, namun bagaimana proses terjadinya dysfuctional behavior masih belum banyak dideskripsikan khusunya terkait dengan pengelolaan keuangan desa. Berdasarkan hal tersebut maka diperlukan pendekatan lain dalam penelitian yang lebih mendalam untuk bisa menyajikan bagaimana dysfuctional 
behaviorberlangsung dan bagaimana pemahaman serta pengalaman pelaku (sebagai informan) sebagai pelengkap temuan dari kajian empiris sebelumnya.

Fajri et al. (2012) menyatakan bahwa pengelolaan Alokasi Dana Desa (ADD) di Desa Ketindan masih ditemukan kesalahan dan penyimpangan, sehingga pada rekomendasinya disebutkan agar pemerintah desa memperhitungkan dan mengklasifikasikan secara tepat program yang akan dibiayai ADD serta berupaya menambah sumber pendapatan desa sesuai dengan potensi yang dimiliki desa. Kajian tersebut belum menyajikan bagaimana proses pengelolaan berlangsung dan apa penyebab terjadi penyimpangan. Hal itu penting disajikan agar rekomendasi yang dihasilkan dari kajian tersebut, terutama terkait manfaat praktis dan kebijakan dapat memberikan kontribusi yang tepat.

Berdasarkan hal diatas, maka kajian bagaimana proses dan makna sesungguhnya dari perilaku dan pengalaman informan berkontribusi dalam sebuah realita terjadinya dysfunctional behavior dalam pengelolaan keuangan khususnya keuangan desa masih diperlukan. Hal ini memotivasi peneliti untuk mengkaji fenomena dysfunctional behavior dalam pengelolaan keuangan khususnya pada desa di Kabupaten Samanta pada perspektif yang lebih mendalam melalui interpretasi dan pemaknaan informan terhadap obyek yang terlibat. Kajian dan pendekatan terhadap dysfunctional behavior dalam pengelolaan keuangan desa ini diharapkan sebagai orisinalitas penelitian. Kajian ini juga akan dikaitkan dengan implementasi UU No. 6/2014 beserta turunannya, yang merupakan kebijakan baru pemerintah. Sebagai sebuah kebijakan baru, maka peneliti berharap fokus kajian penelitian ini menjadi sebuah kebaruan untuk memperkaya kajian akuntansi sektor publik khususnya terkait dengan pengelelolaan keuangan desa

Kajian dysfunctional behavior khususnya dalam pengelola keuangan sektor publik, terutama terhadap pengelolaan keuangan desa belum banyak disajikan secara mendalam dan holistik. Berbagai simpulan dari kajian empiris sebelumnya terkait dysfunctional behavior cenderung hanya menyajikan determinan dan implikasi, namun bagaimanakah proses berlangsung masih terbatas disajikan karena kesulitan peneliti mendapatkan informasi dari pelaku/informan. Oleh karena itu diperlukan penelitian dengan pendekatan yang berfokus pada pengalaman, pemahaman serta interpretasi perilaku sebagai pengelola keuangan. Variasi pendekatan untuk mengungkapkan makna dan motivasi sesungguhnya secara holistik, tidak terbatas pada realita dan data yang nampak, dengan demikian akan diketahui tidak terbatas pada bagaimana proses dysfunctional behavior.

Implikasi nyata UU No. 6/2014 adalah terdistribusinya anggaran ke desa dalam jumlah yang cukup besar diikuti juga oleh peningkatan wewenang dan tanggungjawab pengelolanya. Secara normatif dapat dinyatakan bahwa adanya berbagai regulasi, sosialisasi, bimbingan dan pelatihan serta dukungan tenaga pendamping desa sejatinya menjadikan pengelola keuangan desa melaksanakan tugasnya secara baik (sesuai ketentuan dan pedoman), serta dapat mencegah atau mengurangi dysfunctional behavior. Meskipun berbagai fakta dari fenomena menunjukkan dysfunctional behavior terjadi dalam pengelolaan keuangan desa di Kabupaten Samanta. Oleh karena itu, pertanyaan dalam penelitian ini diajukan untuk memahami perilaku dan makna sesungguhnya dari pengalaman dan pemahaman para pengelola keuangan desa di Kabupaten Samanta. Pertanyaan peneliti dalam usulan penelitian ini adalah: bagaimana implementasi pengelolaan pendapatan desa yang bersumber dari bantuan keuangan pemerintah kabupaten untuk desa-desa di Kabupaten Samanta?; dan apakah dampak dan implikasi dysfunctional behavior yang terjadi dalam pendapatan desa yang bersumber dari bantuan keuangan pemerintah kabupaten pada desa-desa di Kabupaten Samanta?.

Usulan penelitian ini menggunakan paradigma interpretive yang merupakan salah satu kombinasi dari pandangan-pandangan mengenai asumsi sifat dasar ilmu sosial dan sifat dasar masyarakat (Burrel dan Morgan, 1979:29 dalam Kamayanti, 2015). Sebagai paradigma yang berakar pada sociology of regulation dengan sudut pandang subjektif, maka perhatian utamanya ada pada bagaimana memahami "dunia" sebagaimana adanya, memahami tabiat fundamental dari dunia sosial dari pengalaman subjektif seseorang yang terlibat langsung. Tujuan penelitian ini 
untuk memahami, mengkaji dan memaknai kenyataan sosial menurut apa adanya, yakni mencari sifat yang paling dasar dari kenyataan sosial menurut pandangan subjektif dan kesadaran seseorang yang langsung terlibat dalam peristiwa sosial bukan menurut orang lain yang mengamati. Kenyataan sosial muncul karena dibentuk oleh kesadaran dan tindakan seseorang. Oleh karena itu, peneliti akan berusaha menyelami jauh ke dalam kesadaran dan subjektivitas Informan untuk menemukan pengertian apa yang ada di balik realita yang nampak. Maka tujuan penelitian ini adalah: memahami, mengkaji dan memaknai perilaku pengelola keuangan desa di Kabupaten Samanta; dan memahami, mengkaji dan memaknai proses terjadinya dysfunctional behavior dalam pengelolaan keuangan desa di Kabupaten Samanta serta mengetahui dampak dan implikasi yang sesungguhnya, terkait dengan pengelolaan salah satu sumber pendapatan desa yakni bantuan keuangan pemerintah kabupaten.

Peneliti menyajikan beberapa kajian teoritis serta konsep yang relevan konteks fenomena penelitian ini, namun kajian teori serta konsep yang disajikan tidak eksplisit dikaitkan dengan fenomena. Hal ini berdasarkan pendapat Schwandt (1993) dalam Creswell (2016) yang menyatakan bahwa penelitian kualitatif tidak murni untuk mengobservasi teori, sehingga teori bersifat "pasif" dan hanya menjadi starting point bagi keseluruhan observasi. Teori hanya sebagai "bantuan" bagi peneliti dalam menentukan perspektif sesuai rumusan masalah yang diajukan (Cresswel, 2016:68). Sesuai logika induktif (Punch, 2005 dalam Cresswel, 2016:87), teori tetap akan menjadi end poin research karena penelitian dimulai dari pengumpulan data, lalu ke tema-tema umum, yang selanjutnya akan menuju sebuah pola, model dan berakhir pada teori tertentu.

Teori-teori yang disajikan dalam usulan penelitian ini bersifat sementara, karena dinamika dari karakteristik permasalahan dalam penelitian ini dapat bersifat sementara. Peneliti akan berusaha "melepaskan diri" dari teori-teori tersebut dengan lebih mengedepankan data "sebagaimana adanya" yang diperoleh dan yang terjadi dilapangan, apa yang dialami, dirasakan dan difikirkan oleh informan, bukan data "sebagaimana seharusnya". Peneliti akan mendeskripsikan realitas yang ada secara mendalam dan terperinci untuk berusaha membangun esensi pengalaman dari informan (Riemen, 1986 dalam Creswell, 2016). serta mementingkan emic perspective, bergerak dari fakta, informasi atau peristiwa menuju ke tingkat abstraksi yang lebih tinggi, apakah itu konsep atau teori (Kuswarno, 2009). Hasil akhir penelitian ini diharapkan dapat menambah literatur tentang aplikasi maupun justifikasi beberapa teori diatas dalam akuntansi sektor publik khususnya tentang pengelolaan keuangan desa.

Manfaat teoritis lainnya yang diharapkan peneliti adalah menindaklanjuti penelitian Cole, Bruch, \& Walter (2008); Raghunandan et al. (2012) dan MacKenzie, Garavan, \& Carbery (2011), yang menyatakan keterbatasan kajian dysfunctional behavior disebabkan kesulitan mendapatkan informasi dari pelaku sebagai informan. Penelitian ini juga untuk melaksanakan rekomendasi penelitian Alemu (2016); Otterlo (2013); Jones (2005); Danish et al. (2014); Bagire \& Namada (2013); Nahruddin (2014) yang meyakini bahwa selain aspek teknis, aspek non teknis dalam pengelolaan keuangan juga penting, sehingga para peneliti tersebut mengarahkan agar penelitian mendatang tidak hanya fokus pada unsur teknis, namun juga terkait dengan unsur non teknis. Unsur non teknis yang dimaksudkan adalah perilaku dan pengalaman Informan yang dalam kajiannya dapat dilakukan secara holistik dan penyajian hasilnya dapat lebih mendalam sampai dengan makna sesungguhnya dari pengalaman dan pemahaman Informan.

Hasil penelitian ini sebagai masukan bagi Pemerintah Kabupaten Samanta, agar kegiatan pembinaan yang dilakukan dapat tepat sasaran, sesuai dengan permasalahan atau kelemahan yang ditemukan oleh lembaga yang melaksanakan pengawasan maupun pemeriksaan. Bagi pemerintah desa di Kabupaten Samanta, hasil penelitian ini dapat menjadi salah satu literatur dan referensi dalam menentukan kebijakan pengelolaan anggaran desa, agar sesuai regulasi dan ketentuan yang telah ditetapkan. Harapan selanjutnya agar pengelolaan yang dilaksanakan dapat memberikan manfaat yang sebesar-besarnya bagi kebaikan dan kesejahteraan masyarakat desa

Hasil penelitian ini diharapkan dapat digunakan sebagai salah satu pertimbangan bagi Pemerintah, agar dysfunctional behavior dalam pengelolaan keuangan desa dapat di minimalisir. 
Hasil penelitian ini juga diharapkan dapat menjadi pertimbangan bagi pemerintah, agar kebijakan yang diatur dalam berbagai regulasi dapat disesuaikan. Hal ini sejalan dengan kajian Ely (2009) dan Etienne (2010) yang dinyatakan berpeluang mempengaruhi tingkat keberhasilan pengelolaan keuangan. Materi dan proses sosialisasi setiap regulasi harus menjadi perhatian pemerintah pusat dan pemerintah kabupaten, karena regulasi yang di tetapkan pemerintah daerah (peraturan daerah, peraturan bupati, keputusan bupati) tentu berpedoman pada regulasi lebih tinggi (undang-undang, peraturan pemerintah, peraturan menteri) yang ditetapkan sebelumnya oleh pemerintah pusat. Selain itu, kebijakan yang ditentukan oleh pemerintah terkait pengelolaan keuangan desa, tidak hanya difokuskan pada upaya peningkatan kapasitas pengelola keuangan desa saja, tapi lembaga dan instansi yang terkait dengan pembinaan dan pengawasan pengelolaan keuangan desa juga harus mendapat perhatian dan dukungan. Hal ini mutlak diperlukan karena perubahan regulasi desa melalui UU No. 6/2014 tidak hanya berpengaruh terhadap desa, tetapi berkaitan erat dengan berbagai pelaksanaan tugas dan fungsi pada berbagai organisasi perangkat daerah lainnya.

\section{METODE}

Desain penelitian ini adalah penelitian kualitatif untuk mendapatkan wawasan tentang sesuatu yang baru sedikit diketahui dan mendapatkan rincian yang lebih kompleks terkait fenomena pada pengelolaan keuangan desa. Fenomena diproksikan sebagai hasil penangkapan gejala yang bisa dipahami oleh pikiran manusia, sehingga peneliti dapat membangun makna atas berbagai gejala, realitas dan aktivitas manusia yang saling berhubungan (Triyuwono, Mulawarman, Djamhuri, \& Prawironegoro, 2016). Pendekatan penelitian ini adalah fenomenologi-hermeneutika (Ricoeur, 2014), yang menganggap fenomenologi tidak bisa berdiri sendiri, harus didampingi oleh hermeneutika, karena bahasa (ucapan, ungkapan, tindakan) dan teks merupakan peran yang sangat esensial dalam pendekatan fenomenologi-hermeneutika, sehingga melalui interpretasi bahasa dan teks, noumena bisa dimaknai dengan baik. Penelitian ini berfokus pada bagaimana memahami 'dunia' sebagaimana adanya, memahami tabiat fundamental dunia sosial dari pengalaman subjektif seseorang yang terlibat langsung, bukan menurut orang lain yang mengamati (Burrel dan Morgan, 1979 dalam Kamayanti, 2015). Oleh karena itu, peneliti akan berusaha 'menyelami' lebih dalam untuk menemukan noumena di balik realita yang nampak. Adanya makna dalam kehidupan sosial itu karena adanya kebiasaan yang terstruktur, sehingga seorang peneliti disebutkan harus mampu mengetahui makna dibalik hal itu melalui gejala yang nampak (Triyuwono et al., 2016).

Informan penelitian ini adalah pengelola keuangan desa di Kabupaten Samanta yang terlibat langsung pada proses pengelolaan keuangan desa, yaitu: kepala desa, perangkat desa dan bendahara desa di Kabupaten Samanta. Penentuan lokasi penelitian mempertimbangkan keterbatasan penelitian sebelumnya, dimana peneliti yang mengkaji perilaku yang menyimpang kesulitan mendapatkan informasi karena keterbatasan pemahaman personal factors informan yang akan mempengaruhi 'keterbukaan' informan. Dalam penelitian ini, peneliti akan melakukan komunikasi yang lebih baik, terbuka dan intens dengan informan, dengan memanfaatkan kemampuan dan pengetahuan peneliti terhadap karakter, bahasa dan budaya setempat atau emphatic neutrality(Patton, 2002). Selain itu, dengan menggunakan 'aspek kemanusiaan' akan mempermudah peneliti mengakses situs dan mengoleksi data berdasarkan trustworthiness dan authenticity(Kamayanti, 2015).

Data primer dikumpulkan melalui wawancara secara langsung dengan informan. Selain wawancara, peneliti juga melakukan pengamatan terhadap tindakan atau kegiatan informan terkait dengan fokus penelitian. Hasil wawancara akan dicatat dan dibantu alat perekam. Pengumpulan data pendukung juga dilakukan selama proses berlangsungnya penelitian ini, berupa foto-foto, dokumen, atau naskah yang relevan termasuk naskah yang dijadikan refrensi atau pedoman yang relevan. Pengumpulan data dengan wawancara ini akan dihentikan ketika berbagai pola yang terbentuk dalam tiap model sudah jenuh, sebagai upaya peneliti untuk benar-benar dapat 
memahami apa yang telah dialami oleh "Aku" sehingga "Aku" melakukan pemaknaan atas suatu hal tertentu (Kamayanti, 2016).

Temuan data lapangan akan dikelompokkan menjadi tema, model dan pola-pola. Metode analisis data dalam perspektif fenomenologi merujuk pada Moustakas (2009), selanjutnya akan dikolaborasikan dengan metode analisis data hermenuetika (Ricoeur, 2014). Keterkaitan tiap langkah dalam kedua analisis data merupakan proses simultan atau learning by doing (Dey, 1993 dalam Creswell, 2015). Pola-pola yang menjadi temuan data lapangan akan dideskripsikan tentang 'apakah' yang dialami, dipahami atau diyakini oleh informan dalam fenomena (deskripsi tekstural) dari pengalaman tersebut (apa yang terjadi). Selanjutnya akan dideskripsikan pula tentang 'bagaimana' pengalaman tersebut terjadi (deskripsi struktural), dan peneliti membahas tentang latar dan konteks dimana fenomena tersebut dialami. Pada bagian akhir, peneliti akan mendeskripsikan fenomena dengan memasukkan deskripsi tekstural dan deskripsi strukural. Bagian ini merupakan 'esensi' dari pengalaman tersebut yang akan memberikan penuturan tentang 'apa' yang dialami informan dengan fenomena tersebut dan 'bagaimana' informan mengalaminya. Selain melaksanakan analisis data, peneliti juga akan tetap mendalami literatur tertentu guna mengkonfirmasi suatu teori atau konsep yang barangkali ditemukan dari proposisi yang berasal dan terkait dengan data yang ditemukan (Moleong, 2016). Strategi utama untuk menjaga keabsahan data adalah melakukan triangulasi data. Gamar \& Djamhuri (2015) mengemukakan bahwa triangulasi dapat diperoleh dari ketekunan dalam pengamatan, membangun keterlibatan yang empatik, serta memberikan penjelasan sesuai peristiwa yang dilihat, didengar, dan dirasakan oleh peneliti. Selanjutnya peneliti membuat rich and thick description tentang hasil penelitian. Tema, model dan pola yang sudah dikategorisasi dianalisis untuk menemukan refleksi peran dan pemahaman para informan yang berpotensi membentuk interpretasinya terhadap suatu pemaknaan dan tindakan. Konsep fokus analisa temuan data lapangan yang diajukan peneliti disajikan pada Gambar 1 berikut:

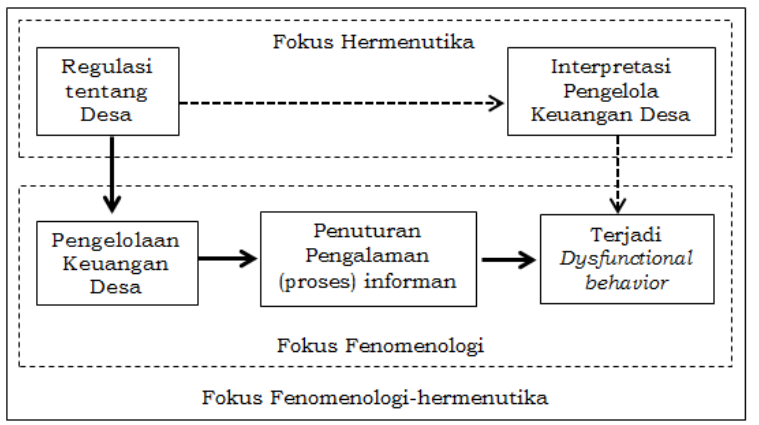

Gambar 1. Fokus Analisis Data Fenomenologi-hermeneutika (Ricoeur, 2014)

Konsep peneliti terhadap fokus penelitian ini merujuk pada pendapat Wisri \& Mughni (2016), yang menyatakan bahwa fenomenologi memberikan atensi lebih besar pada sifat pengalaman yang dihidupkan, sedangkan hermeneutika berkonsentrasi pada masalah-masalah yang muncul dari interpretasi tekstual.Maka selain sebagai metode interpretasi teks dan bahasa, hermeneutika juga digunakan untuk mengkaji dan mencari noemena, sebagaimana manusia sebagai subyek memaknai obyek-obyek di sekitarnya (Mulyono, 2013).

\section{HASIL DAN PEMBAHASAN}

UU No. 6/2014 pasal 1 ayat (8) menyatakan bahwa pembangunan desa merupakan upaya peningkatan kualitas hidup dan kehidupan dalam rangka peningkatan kesejahteraan masyarakat yang sebesar-besarnya. Salah satu implikasi terimplementasinya regulasi tersebut, desa memiliki kewenangan untuk mengelola keuangannya secara mandiri. Keuangan desa merupakan semua hak dan kewajiban desa yang dapat dinilai dengan uang serta segala sesuatu berupa uang dan barang yang berhubungan dengan pelaksanaan hak dan kewajiban desa (psl. 1 ayat 10). Sebagai pedoman 
bagi aparatur pemerintah desa sebagai pengelola keuangan desa, maka pemerintah menerbitkan Permendagri No. 113/2014 dan memberi amanat kepada pemerintah kabupaten untuk ditindaklajuti dengan membuat regulasi terkait sesuai kondisi daerah masing-masing.

Regulasi ini mengatur bahwa pelaksanaan pengelolaan keuangan desa harus mengedepankan upaya untuk memberdayakan masyarakat desa. Pemberdayaan masyarakat desa adalah upaya sebuah untuk mengembangkan kemandirian dan kesejahteraan masyarakat dengan meningkatkan pengetahuan, sikap, keterampilan, perilaku, kemampuan, kesadaran, serta memanfaatkan sumber daya melalui penetapan kebijakan, program, kegiatan, dan pendampingan yang sesuai dengan esensi masalah dan prioritas kebutuhan masyarakat desa (psl. 1 ayat 12 UU No. 6/2014). Kebijakan yang ditetapkan pemerintah tersebut juga bertujuan untuk memajukan perekonomian masyarakat desa, terutama melalui pengentasan kesenjangan pembangunan nasional dan memperkuat masyarakat desa sebagai subjek pembangunan.

Terkait dengan pendapatan, desa memiliki berbagai sumber pendapatan dalam rangka membiayai pelaksanaan berbagai kegiatan yang merupakan kewenangan desa. Pasal 102 PP No. 47/2015 menyebutkan bahwa bupati menginformasikan rencana alokasi dana desa, bagian dari bagi hasil pajak dan retribusi kabupaten untuk desa, serta bantuan keuangan yang bersumber dari anggaran pendapatan dan belanja daerah kabupaten. Informasi tersebut harus disampaikan pemerintah daerah kepada kepala desa dalam jangka waktu 10 (sepuluh) hari setelah kebijakan umum anggaran dan prioritas serta plafon anggaran sementara disepakati kepala daerah bersama dewan perwakilan rakyat daerah. Informasi dari pemerintah daerah tersebut menjadi bahan penyusunan rancangan APBDesa.

Pendapatan yang diakui oleh pemerintah desa adalah semua penerimaan yang melalui rekening desa. Pendapatan dana transfer yang diperoleh desa antara lain Dana Desa (DD) yang bersumber dari APBN, ADD, Bagi Hasil Pajak dan Retribusi Daerah yang bersumber dari APBD kabupaten. Selain itu, pemerintah desa juga menerima bantuan keuangan dari pemerintah provinsi dan pemerintah kabupaten, sebagaimana dinyatakan dalam Pasal 98 ayat (1) PP No. 47/2015:

"Pemerintah daerah provinsi dan pemerintah daerah kabupaten dapat memberikan bantuan keuangan yang bersumber dari anggaran pendapatan dan belanja daerah provinsi dan anggaran pendapatan dan belanja daerah kabupaten kepada desa".

Berdasarkan temuan data lapangan, pada tahun 2015-2016, nilai bantuan keuangan yang diterima desa-desa dari Pemerintah Kabupaten Samanta, bervariasi pada rentang Rp180jt sampai dengan Rp550jt. Informasi yang diterima desa terkait nilai bantuan keuangan tersebut diperoleh setelah penetapan APBDesa. Hal itu menjadikan pemerintah daerah tidak konsisten dengan ketentuan yang diatur dalam Pasal 102 PP No. 47 Tahun 2015. Namun hal itu menjadi tidak terlalu berdampak terhadap penentuan alokasi belanja 30\% dan $70 \%$ dari total pendapatan dalam APBDesa yang diatur pada Pasal 81 dan pasal 100 PP No. 47 Tahun 2015. Selain itu, berdasarkan dokumen pemberitahuan pemerintah daerah yang disampaikan ke pemerintah desa, ditemukan juga bahwa anggaran tersebut telah ditentukan peruntukannya (jenis pekerjaannya) serta lokasi pelaksanaan pekerjaan tersebut. Berdasarkan karakteristik anggaran tersebut, menjadikan anggaran itu termasuk sebagai anggaran yang bersifat khusus. Pada Pasal 98 ayat (2) Peraturan Pemerintah Nomor 47 Tahun 2015 menyebutkan bahwa bantuan keuangan yang diberikan oleh pemerintah provinsi maupun pemerintah kabupaten dapat bersifat umum dan khusus. Ketentuan untuk masingmasing jenis atau sifat anggaran tersebut dijelaskan lebih lanjut pada Pasal 98 ayat (3) dan (4) berikut ini:

"Bantuan keuangan yang bersifat umum, peruntukan dan penggunaannya diserahkan sepenuhnya kepada desa penerima bantuan dalam rangka membantu pelaksanaan tugas pemerintah daerah di desa";

"Bantuan keuangan yang bersifat khusus, peruntukan dan pengelolaannya ditetapkan oleh pemerintah daerah pemberi bantuan dalam rangka percepatan pembangunan desa dan pemberdayaan masyarakat". 
Memperhatikan ketentuan pada regulasi di atas, faktanya menunjukkan bahwa kebijakan tersebut tidak sepenuhnya terimplementasi dengan tepat. Hal ini disebabkan tidak transparannya pemerintah Kabupaten Samanta terhadap tujuan dari anggaran melalui bantuan keuangan khusus tersebut. Terkait dengan transparansi atas anggaran pemerintah, Pradana (2014) menyatakan bahwa anggaran yang terbuka kepada publik dan ke partisipan dalam proses pengambilan kebijakan, dan mengkonsolidasi informasi terkini merupakan proses transparansi dalam penganggaran. Maka sebagai dana publik, kebijakan terhadap pengelolaan anggaran itu pada dasarnya adalah suatu kebijakan yang dirumuskan berkaitan dengan pemberdayaan masyarakat desa selain untuk membantu membiayai berbagai program desa. Hal ini ditegaskan Dwiyanto (2003) dalam Pradana (2014) yang menyatakan bahwa pengelolaan dana atau anggaran yang dimiliki oleh pemerintah kabupaten harus memperhatikan prinsip-prinsip transparansi, seperti menyangkut legalitas sumber anggaran, mekanisme penggunaan anggaran, alokasi anggaran, dan pertanggungjawaban anggaran harus dapat dimonitor oleh publik secara luas.

Temuan data lapangan, baik pernyataan informan maupun dokumen-dokumen yang relevan menunjukkan bahwa selain peruntukan (jenis pekerjaan dan lokasi pekerjaan), pemerintah daerah juga telah menentukan pelaksana dari pekerjaan tersebut. Sehingga pemerintah desa tidak melakukan pengelolaan sebagai yang telah ditetapkan pada regulasi diatas. Pengelolaan yang semestinya dilakukan oleh pemerintah desa, pada faktanya dilaksanakan oleh 'pihak lain' di luar pengelola keuangan desa. implementasi tersebut menunculkan berbagai persoalan bagi pengelola keuangan desa. Hal itu terungkap dalam salah satu penuturan informan A1 berikut ini:

"bantuan khusus (bantuan keuangan pemerintah Kabupaten Samanta) itu merupakan aspirasi dewan (anggota DPRD Kabupaten Samanta) yang mengerjakan proyek dana aspirasi dewan itu kan orang dewan (anggota DPRD) yang mengusulkan atau orang dari tim sukses anggota dewan itu, tapi kita (pemerintah desa) yang disuruh bertanggungjawab, jadi hal itu masuk juga dalam laporan kami, malah kami (kepala desa) yang disuruh menandatangani fakta integritas terkait pekerjaan itu, padahal kan tidak ada fungsi kami dalam pelaksanaan pekerjaan itu, karena yang mengerjakan adalah orang lain, orang dari luar desa ini, selain itu, anggarannya juga masuk ke dalam rekening desa ini, makanya hal itu menjadi beban besar bagi kami, pada SPJ-nya proyek aspirasi dewan itu, saya menandatangi berkas diatas 8 materai, artinya kalau masuk ke rekening desa jadi pendapatan desa kan?... kan seharusnya kami yang menentukan pelaksanaan atau menjalankan pekerjaan itu, karena biasanya, jangankan mau buat SPJ pelaksana proyek dana aspirasi itu, nota-nota pembelian materialnya saja tidak tertib dikumpulkan, tapi tidak pernah jadi temuan Inspektorat hal itu (SPJ pekerjaan dana aspirasi) karena kami mau tidak mau harus membuat lengkap SPJ-nya, karena sudah dibebankan tanggungjawab itu kepada kami, sampai lengkap nota-nota, bukti belanjanya, itu kami cari dan kami kumpulkan, kami lengkapi itu terutama pada toko-toko yang biasa bekerjasama dengan kami, bahkan pernah sampai Rp50jt bisa kami buat lengkap buktibukti SPJ-nya, caranya... kami kumpulkan nota pembelian material dari masyarakat yang sedang membangun atau merehab rumah, yang pernah membeli semen, besi, kerikil, batu, nota-nota masyarakat itu yang kami jadikan nota untuk bukti SPK pekerjaan dana aspirasi itu, sampai-sampai pembelian material masjid kami gunakan untuk "menutupi" SPJ pekerjaan itu" (tgl. 7/2/2017 di kantor kepala desa A1).

Memaknai penuturan di atas, kebijakan pemerintah yang diatur dalam PP No. 47/2015 tidak terimplementasi akibat ketidakkonsistenan pemerintah daerah.Kebijakan pemerintah yang diatur dalam PP No. 47/2015 khususnya pada Pasal 98 ayat (3) dan (4) juga mengamanatkan pemerintah daerah sebagai pemberi bantuan agar memberdayakan masyarakat desa sebagai upaya percepatan pembangunan desa juga menjadi tidak terimplementasi. Hal ini disebabkan karena penentuan konsultan perencana, kontraktor pelaksana telah ditentukan sebelumnya oleh pemerintah daerah. Temuan data lapangan menunjukkan bahwa bantuan keuangan yang bersifat khusus dari pemerintah Kabupaten Samanta memiliki nilai yang bervariasi pada masing-masing desa, antara 
$100 j \mathrm{j}$ s/d 500jt. Masyarakat desa di Kabupaten Samanta, menyebut proyek pekerjaan yang bersumber dari bantuan keuangan khusus dari Pemerintah Kabupaten Samanta itu sebagai "proyek dana aspirasi dewan". Sebutan itu berdasarkan proses dan sistem pelaksanaannya sebagaimana dituturkan oleh para informan, benar-benar bersifat 'khusus' karena sudah ditentukan arah, lokasi penggunaannya serta siapa pelaksananya. Namun walaupun masuk dalam pendapatan desa, selain tidak melakukan pengelolaan sebagaimana pendapatan desa lainnya, pemerintah desa juga tidak dapat menjadikan pendapatan tersebut sebagai dasar penentuan jumlah penghasilan tetap dan tunjangan pengelola keuangan desa. Hal ini dinyatakan pada Pasal 11 ayat (3) Perbup Samanta No. 12/2014, berikut ini:

"bantuan keuangan bersifat khusus dikelola dalam APBDesa tetapi tidak diterapkan dalam ketentuan penggunaan paling sedikit $70 \%$ (tujuh puluh perseratus) dan paling banyak 30\% (tigapuluh perseratus).

Ketentuan di atas menjadikan pengelola keuangan desa menjadi tidak 'termotivasi' untuk mengelola secara baik anggaran tersebut. Namun karena sudah menjadi ketentuan, bahwa segala penerimaan desa yang melalui rekening desa wajib dipertanggungjawabkan pengelola keuangan desa menjadikan anggaran tersebut masuk sebagai bagian dari anggaran yang harus dilaporkan serta dipertanggungjawabkan sebagaimana pendapatan dan penerimaan desa lainnya.

Seluruh pendapatan desa diterima dan disalurkan melalui rekening kas desa dan penggunaannya ditetapkan dalam APBDesa. Rekening kas yang dimiliki tiap desa adalah rekening tempat menyimpan uang pemerintahan desa yang menampung seluruh penerimaan desa dan digunakan untuk membayar seluruh pengeluaran desa pada bank yang ditetapkan (psl.1 ayat 17). Proses pencairan dana dalam rekening kas desa, sebagaimana penerimaan desa lainnya ditandatangani oleh kepala desa dan bendahara desa. Permendagri No. 113/2014 menyebutkan bahwa penerimaan desa merupakan seluruh uang yang berasal dari seluruh pendapatan desa yang masuk ke APBDesa melalui rekening kas desa, demikian juga selanjutnya terkait dengan pengeluaran desa merupakan uang yang dikeluarkan dari APBDesa melalui rekening kas desa (psl. 1 ayat 18$)$.

Sebagai rencana tahunan keuangan pemerintah desa, maka APBDesa sebagaimana disebutkan dalam Pasal 1 ayat (12) Peraturan Menteri Dalam Negeri Nomor 113 Tahun 2014, menjadikan kepala desa sebagai pemegang kekuasaan tertinggi dalam pengelolaan keuangan desa, yang karena jabatannya mempunyai kewenangan menyelenggarakan keseluruhan pengelolaan keuangan desa.Pengelolaan yang dilakukan oleh pihak di luar pengelola keuangan desa, menjadikan timbulnya berbagai persolan, baik dari tahap perencanaan sampai dengan pertanggungjawaban. Pada tahap perencanaan, temuan-temuan tim pemeriksa (Inspektorat Kabupaten Samanta) terhadap pengelolaan keuangan desa selalu muncul dari kegiatan yang 'dikelola' oleh pihak di luar pengelola keuangan desa tersebut. orang-orang atau pihak yang mengerjakan dokumen perencanaan pekerjaan konstruksi yang bersumber dari bantuan keuangan yang bersifat khusus dari Pemerintah Kabupaten Samanta itu, adalah "orang suruhan" anggota DPRD (yang disebut sebagai 'pemilik' atau yang 'menitipkan' anggaran tersebut melalui APBDesa). Hal itu diantaranya diungkapkan oleh informan A8 berikut ini:

"temuan yang sering muncul itu adalah dokumen perencanaan yang dibuat oleh tim dewan (anggota DPRD) itu, kan ada tenaga perencana khusus para anggota DPRD itu untuk proyek dana apsirasinya yang masuk ke desa kami ini, kami dan inspektorat itu mengacu pada harga standar bupati itu, tapi konsultan dana aspirasi itu menggunakan harga lokal setempat, sehingga ada perbedaan nilai analisa antara konsultan dana aspirasi dengan konsultan kami, kami lebih rendah, tapi karena kami yang "disuruh" bertanggungjawab atas anggaran dan fisik kegiatan itu (proyek dana aspirasi dewan) oleh pemerintah daerah, maka kami terpaksa membayar selisih itu, kami diperintahkan membayar kelebihan (atas selisih) ke kas daerah itu, lebih dari 4jt nilainya pak" (tgl. 17/2/2017 di kantor kepala desa A8). 
Selain memiliki masalah pada dokumen perencanaannya, kegiatan atau pekerjaan yang dibiayai dari anggaran bantuan keuangan yang berisfat khusus dari Pemerintah Kabupaten Samanta juga memiliki permasalahan bagi pengelola keuangan desa terkait dengan tahap pelaksanaannya. Berikut kutipan pernyataan dari informan-B8:

"yang jadi masalah di kami itu terkait dana aspirasi yang masuk lewat anggaran bantuan keuangan khusus itu, dipertanggungjawabkan oleh kepala desa, tapi dikerjakan oleh "orang" nya anggota dewan (DPRD) itu, tahun 2017 ini total yang masuk ke desa kegiatan diluar APBDesa ini berjumlah 680jt, tapi yang masuk ke rekening desa hanya 450jt saja, kami direpotkan oleh dana aspirasi itu didalam urusan SPJ-nya, makanya kami meminta, toong diadakan atau dibuat semuanya saja dokumennya, dari perencanaan sampai SPJ-nya langsung oleh konstituen anggota dewan itu, jangan repotkan kami lagi, karena biaya konsultan kami itu hanya untuk kegiatan fisik yang kami anggarkan dalam APBDesa itu saja, kami tetap bertanggungjawab terhadap semua nilai anggaran (yang masuk ke rekening desa), walaupun tidak semua nilainya (nilai dana aspirasi) untuk konstruksi, karena ada biaya konsultan didalamnya" (tgl. 20/2/2017 di kantor kepala desa B8).

Pernyataan di atas menunjukkan bahwa kebijakan yang diimplementasikan oleh pemerintah Kabupaten Samanta, merupakan bentuk dari adanya diskresi kekuasaan yang dimiliki pemerintah. Menurut Darumurti (2012), pendayagunaan kekuasaan yang diskresi (discreationery power) dalam penyelanggaraan pemerintahan sudah menjadi notoir feit. Hal itu dijelaskan lebih lanjut bahwa penyelanggaraan pemerintahan dengan adanya kekuasaan yang diskresi berkaitan erat dengan konsepsi pemerintahan (bestuur) yang disebut dengan istilah bestuurzorg, yaiu suatu fungsi pemerintahan yang tidak hanya mengatur, tetapi juga mengurus. Namun dengan adanya fungsi tersebut menjadikan terjadinya inkonsistensi dari regulasi yang merupakan bentuk kebijakan dari pemerintah itu sendiri.

Tendensi pada adanya kepentingan tertentu dalam pengelolaan bantuan keuangan khusus dalam keuangan desa menjadikan anggaran tersebut tidak terkelola secara tranparan, partisipatif dan akuntabel. Akuntabilitas disebutkan Wicaksono (2015) sebagai salah satu dimensi terhadap akuntabilitas, selain dari adanya aspek pertanggungjawaban, pengendalian, tanggung jawab dan responsivitas. Hal itu menunjukkan bahwa pemerintah Kabupaten Samanta pada umumnya belum mampu menunjukkan tingkat akuntabilitas optimal melalu kebijakan yang digulirkan terhadap pemerintah desa. Hal ini dikarenakan organisasi sektor publik belum sepenuhnya mampu memberikan penjelasan atas penggunaan sumber daya publik dalam menjalankan kebijakan, program, proyek dan aktivitas rutinnya.

Pasal 2 Permendagri No. 113/2014 menyebutkan bahwa keuangan desa dikelola berdasarkan asas-asas transparan (prinsip keterbukaan yang memungkinkan masyarakat untuk mengetahui dan mengakses informasi tentang pengelolaan keuangan desa), akuntabel (pengelolaan keuangan desa harus terkelola secara tepat waktu dan tepat guna, didukung bukti dan kelengkapan administrasi yang dapat dipertanggungjawabkan serta selalu berpedoman pada peraturan perudangundangan yang berlaku), partisipatif (memberikan ruang seluas-luasnya kepada masyarakat untuk ikut aktif terlibat dalam tiap proses dan tahapan pengelolaan keuangan desa) serta dilakukan dengan tertib dan disiplin anggaran. Berbagai prinsip-prinsip tersebut menjadi 'sia-sia' sudah dinyatakan oleh pemerintah, namun pada implementasinya justru pemerintah (daerah) sendiri yang tidak memenuhi prinsip-prinsip tersebut.

Berbagai pertentangan muncul dalam pernyataan para pengelolaan keuangan desa di Kabupaten Samanta terhadap pola pelaksanaan pengelolaan anggaran yang bersumber dari bantuan keuangan pemerintah kabupaten yang bersifat khusus tersebut. Disatu sisi, pemerintah desa mensyukuri adanya bantuan tersebut, karena ikut membantu proses pembangunan, terutama penyediaan sarana dan prasarana infrastruktur desa. Namun disisi lain, anggaran tersebut dianggap memberikan 'bencana' bagi pemerintah desa akibat kebijakan pemerintah daerah yang memperlakukan secara 'khusus' anggaran tersebut. 
Memperhatikan proses pelaksanaan pengelolaan bantuan keuangan dari pemerintah kabupaten yang bersifat khusus tersebut, analogi atau perumpamaan yang diberikan peneliti pada anggaran tersebut adalah 'penumpang gelap' atau free-rider dalam sebuah 'kendaraan' yang bernama APBDesa. Dengan sifatnya yang serba khusus, maka semestinya pemerintah daerah segera menyusun sebuah regulasi atau melakukan evaluasi terhadap berbagai dampak atas kebijakan yang terimplementasi terkait anggaran tersebut. Bupati adalah sebuah jabatan politik yang lahir dari sebuah proses politik, namun sedikit naif jika pemerintah daerah hanya 'sibuk' melakukan pembenaran dan pembelaan diri dan pembelaan terhadap lembaga legislatif sebagai 'pemilik' anggaran tersebut dengan mengabaikan berbagai fakta dan dampak sosial ekonomi yang ditimbulkan dari pola pelaksanaan anggaran khusus tersebut. timbulnya berbagai persoalan dalam pengangaran sektor publik, menurut Razak, Unti, Eko, \& Ermanu (2011) disebabkan adanya keterlibatan lembaga politik dalam proses penganggaran pemerintah daerah, sehingga proses dan dinamika politik ikut mempengaruhi proses pengalokasian sumberdaya yang tentunya akan diikuti konflik kepentingan di antara actors.

Kepentingan pribadi dan perilaku oportunis masing-masing agent (anggota DPRD dan pemerintah daerah) di tingkat pemerintah daerah akan terakumulasi menjadi agents interest dan opportunistic organizational (Latifah, 2010). Hal itu adalah sesuatu yang sangat 'wajar' terjadi pada lembaga pemerintahan daerah karena participatory budgeting system akan selalu memunculkan oportunisme agents akibat adanya agents interest (Eisenhardt, 1989 dan Jackson, 1982 dalam (Abdullah \& Asmara, 2006). Berbagai tindakan yang merupakan sebuah penyimpangan atau fraud dalam penyusunan anggaran sektor publik, termasuk penyusunan APBDesa tersebut menurut Julianto (2012) sesuatu yang sangat lumrah, seolah-olah regulasi (yang dibuat melalui proses politik) didesain memiliki diskresi yang cukup besar untuk 'mengamankan' berbagai kepentingan actors. Hal ini menunjukkan bahwa salah satu penyebab terjadinya penyimpangan itu adalah peraturan perundang-undangan itu sendiri, tentu yang dimaksud adalah regulasi yang memiliki banyak kelemahan dan kekurangan.

Spelt dan Berge (1993) dalam Darumurti (2012) menyebutkan bahwa kekuasaan diskresi itu merupakan konsep yang kontroversial. Hal ini disebabkan karena adanya kepentingan atau inisiatif dari pemerintah itu sendiri atas dasar suatu tujuan. Maka dalam implementasi regulasi terkait dengan pengelolaan keuangan desa yang anggarannya bersumber dari bantuan keuangan pemerintah kabupaten yang bersifat khusus, pemerintah daerah dengan kekuasaan diskresinya 'menabrak' asas the rule of law, mengingat diskresi yang dimiliki mempunyai sifat bawaan kekuasaan yang dijalankan tanpa memperhatikan berbagai karakteristik implementor dan dampak sosial yang ditimbulkan. Hal itu menurut (Darumurti, 2012), dalam prakteknya atau kenyataannya penggunaan kekuasaan diskresi itu berpotensi menimbulkan dampak negatif yang merugikan warga negara atau akan berbenturan dengan kepentingan dan hak warga negara, bahkan akan bertentangan dengan suatu regulasi yang ditetapkan oleh pemerintah itu sendiri.

Regulasi yang diterbitkan pemerintah sebagai produk sebuah kebijakan (Dunn, 2000), baik pemerintah pusat maupun pemerintah daerah banyak yang tidak terimplementasikan dengan baik karena tidak konsisten dengan regulasi lainnya dan tidak sesuai dengan kondisi sebenarnya. Caiden dan Wildavsky (1974) dalam Sulistyowati (2013) menyatakan bahwa sering terjadi inkonsistensi dalam pengelolaan anggaran sektor publik. Hal ini sesungguhnya merupakan hal penting baik secara vertikal maupun horisontal sehingga kebijakan itu dapat dilaksanakan dengan baik dan mencapai hasil sesuai dengan yang direncanakan. Sementara itu, Hofferbert (1974) dalam Parsons (2006) menegaskan bahwa sebuah regulasi sebagai bentuk tertulis sebuah kebijakan pada esensinya merupakan epifenomena, artinya kebijakan itu ditentukan berdasarkan realitas, kondisi historis dan geografis, komposisi sosial dan ekonomi serta mempertimbangkan perilaku eksisting dari implementor, bukan semata-mata hasil sebuah proses politik.

Terjadinya penyimpangan pada pengelolaan dana bantuan keuangan dari Pemerintah Kabupaten Samanta dalam keuangan desa menjadi sebuah indikator bahwa telah terjadi tindakan korupsi. Hal ini merujuk pada pendapat Philp (1997) dalam Santoso (2007) yang mendefinisikan 
bentuk dan aplikasi korupsi. Pertama, korupsi yang berpusat pada kantor publik (public office centered corruption) yang diartikan sebagai tingkah laku atau tindakan pejabat publik yang menyimpang dari tugas-tugas publik formal untukmendapatkan keuntungan pribadi atau bagi orang-orang tertentu yang memiliki hubungan dekat dengan pelaku seperti keluarga, famili dan teman. Pengertian ini mencakup kolusi dan nepotisme. Bentuk korupsi yang kedua adalah korupsi yang berdampak terhadap kepentingan umum (public interest-centered). Dijelaskan bahwahal ini, korupsi terjadi apabila seorang pemegang kekuasaan melakukan penyalahgunaan wewenang karena ada orang yang akan memberikan imbalan (uang atau materi lain) kepadanya. Ketiga, korupsi yang berpusat pada pasar (market-centered), dimanakorupsi yang terjadi melalui "lembaga" ekstra-legal yang digunakan oleh individu atau kelompok untuk mendapatkan pengaruh terhadap kebijakan dan tindakan birokrasi. Kaitan dengan hal ini, korupsi juga berarti penyalahgunaan kekuasaan oleh seorang pegawai atau pejabat pemerintah untuk mendapat tambahan pendapatan dari masyarakat.

Terjadinya berbagai penyimpangan dan yang mengarah pada tindakan korupsi pada pengelolaan bantuan keuangan bersifat khusus tersebut menunjukkan bahwa kebijakan penglaokasian anggaran tersebut tidak berhasil dengan baik. Walaupun demikian, mengingat hajat sesungguhnya sangat bermanfaat, maka diharapkan regulasi yang ditetapkan tersebut benar-benar dapat terimplementasi dengan baik. Realita di atas sejalan dengan core idea dari policy implementation theory yang dikemukakan Mazmanian dan Sebatier (1983) dalam Paudel (2009). Mereka menyatakan bahwa pemaknaan terhadap keberhasilan implementasi kebijakan tidak hanya berfokus pada materi regulasi, proses sosialisasi namun juga bagaimana karakteristik implementor yang terlihat dari berbagai kejadian dan kegiatan yang timbul setelah implementasi.

Teori tersebut menyatakan bahwa terdapat beberapa variabel-variabel yang secara umum mempengaruhi kesuksesan implementasi sebuah kebijakan, yaitu; tractability of the problems (karakteristik dari masalah); ability of statute to structure implementation (karakteristik kebijakan/regulasi); dan non statutory variables affecting implementation (variabel lingkungan). Lebih lanjut dijelaskan bahwa karakteristik masalah dalam implementasi kebijakan disebabkan oleh: tingkat kesulitan teknis dari masalah yang bersangkutan; tingkat kemajemukan kelompok sasaran; proporsi kelompok sasaran terhadap total populasi; dan cakupan perubahan perilaku yang diharapkan.

Teori policy implementation theory yang dikemukakan Mazmanian dan Sebatier (1983) dalam Paudel (2009), juga menyebutkan bahwa karakteristik kebijakan terpengaruh oleh: kejelasan isi kebijakan; seberapa jauh kebijakan tersebut memiliki dukungan teoritis; besarnya alokasi sumberdaya finansial terhadap kebijakan tersebut; seberapa besar adanya keterpautan dan dukungan antar berbagai institusi pelaksana; kejelasan dan konsistensi aturan yang ada pada badan pelaksana; tingkat komitmen aparat terhadap tujuan kebijakan; dan seberapa luas akses kelompokkelompok luar untuk berpartisipasi dalam implementasi kebijakan.

Untuk mengukur keberhasilan implementasi sebuah kebijakan adalah lingkungan kebijakan. Variabel ini lebih lanjut dijelaskan dipengaruhi oleh: kondisi sosial ekonomi masyarakat dan tingkat kemajuan teknologi; dukungan publik terhadap suatu kebijakan; sikap kelompok pemilih (constituency groups). Kelompok pemilih disebutkan dapat mempengaruhi implementasi kebijakan melalui: intervensi terhadap keputusan yang dibuat badan-badan pelaksana melalui berbagai komentar dengan maksud mengubah keputusan; mempengaruhi badan-badan pelaksana secara tidak langsung melalui kritik yang dipublikasikan terhadap kinerja badan-badan pelaksana, dan membuat pernyataan yang ditujukan kepada badan legislatif. Sedangkan unsur terakhir yang disebutkan oleh Mazmanian dan Sebatier (1983) dalam Paudel (2009) sebagai dimensi dari variabel lingkungan kebijakan adalah tingkat komitmen dan ketrampilan dari aparat dan implementor. Komitmen dan keterampilan aparat pelaksana untuk mengimplementasikan amanat regulasi sebagai bentuk kebijakan menjadi unsur penting, karena hal ini terkait dengan prinsip bahwa implementasi kebijakan secara umum merupakan public problem solving. 
Perlakukan yang berbeda terhadap pendapatan desa dari bantuan anggaran pemerintah kabuoaten yang bersifat khusus tersebut pada beberapa desa lebih merupakan 'musibah' daripada 'anugerah'. Hal itu diungkapkan karena kepala desa harus bertanggungjawab terhadap anggaran tersebut serta output dari pelaksanaannya walaupun bukan kepala desa yang mengelola anggaran tersebut. Berbagai penyimpangan yang menjadi temuan Inspektorat tetap menjadi tanggungjawab pengelola keuangan desa. Hal ini mengingat posisi anggaran tersebut yang menjadi dana transfer, masuk ke rekening kas desa dan selanjutnya menjadi pendapatan desa, yang walaupun tidak dapat 'diakui' untuk dihitung sebagai pengalokasian penghasilan tetap dan atau tunjangan. Selain itu, dalam pertanggungjawaban atas pelaksanaan anggaran dari pendapatan ini, kepala desa sebagai pengelola keuangan desa juga membubuhkan tandatangannya di atas materai yang diantaranya merupakan surat pernyataan pertanggungjawaban terhadap keberadaan anggaran tersebut. Pada pelaksanaannya, orang suruhan dari 'pemilik' anggaran khusus tersebut yang melaksanakan pekerjaan dilapangan sebagaimana layaknya seorang penyedia jasa. Setelah menyelesaikan pekerjaannya, rekanan tersebut melapor kepada kepala desa, dan kepala desa (mengikuti mekanisme normatif) memerintahkan Panitia Penerima Hasil Pekerjaan (PPHP) melakukan pemeriksaan. Setelah PPHP menandatangi berita acara pemeriksaan dan berita acara serah terima, maka perangkat desa yang menjadi Pelaksana Teknis Pengelola Keuangan Desa (PTPKD) atas jenis pekerjaan itu membuat SPJ. Sesuai dengan sifatnya yang 'khusus', maka proses penyusunan SPJ-nya juga dilakukan secara 'khusus' pula. Walaupun yang menyusun dokumen perencanaan dan pelaksanaan pekerjaan di lapangan, belanja material, mencari tukang adalah orang suruhan 'pemilik' anggaran khusus tersebut, namun yang membuat SPJ adalah PTPKD itu sendiri. Para informan mengeluhkan hal tersebut, namun keberanian yang tanpa pemahaman dan pengetahuan terkait dengan kebijakan pemerintah tersebut, menjadikan praktek penyimpangan, fraud dalam pengelolaan keuangan desa 'terpelihara' dan 'dibenarkan'. Tidak sedikit para pengelola keuangan desa yang sesungguhnya menolak, namun bagi mereka (pengelola keuangan desa di Kabupaten Samanta) akan menjadi persoalan baru ketika harus 'berhadapan' dengan 'penguasa-penguasa' aerah, yakni pihak eksekutif dan legislatif, maka dengan penuh keterpaksaan dan dibawah tekanan para pengelola keuangan desa tetap berusaha menutupi berbagai penyimpangan yang terjadi. Hal ini tidak merata terjadi pada desa-desa di Kabupaten Samanta, karena beberapa kasus pekerjaan dari sumber kegiatan tersebut sudah terekspose media dan pihak penegak hukum telah menetapkan beberapa tersangka. Perbadingan antara jumlah pengungkapan (exposure) dengan jumlah penyimpangan anggaran tersebut tidak sebanding dengan jumlah desa di Kabupaten Samanta yang juga 'menjalani' dan 'mengalami' persoalan tersebut.

Tidak terungkapnya berbagai penyimpangan tersebut, karena pada beberapa desa, tenaga pelaksana dari proyek dana aspirasi dewan tersebut cukup 'berbaik hati' dengan mau mengumpulkan bukti belanja atas material tertentu menyerahkannya kepada perangkat desa sebagai bahan kelengkapan pembuatan SPJ dan tidak lupa memberikan 'imbalan jasa' atas pembuatan SPJnya. Namun pada beberapa desa lainnya (ini yang dominan), pelaksana proyek 'angggaran khusus' ini sepenuhnya menyerahkan SPJ-nya untuk di 'urus' pengelola keuangan desa. Maka sebagai sebuah 'kewajiban", pengelola keuangan desa akan berupaya mengumpulkan bukti-bukti atas pembelanjaan terkait proyek khusus tersebut dengan berbagai upaya, pastinya semuanya dimanipulasi untuk memenuhi kelengkapan SPJ proyek dari anggaran khusus tersebut.

Banyaknya persoalan terkait dengan pengelolaan kegiatan yang bersumber dari bantuan keuangan Pemerintah Kabupaten Samanta, dinyatakan oleh beberapa informan karena perlakuan 'khusus' terhadap anggaran tersebut. selain itu, berbagai pertanyaan, persepsi, serta harapan dari para pengelola keuangan desa di Kabupaten Samanta juga terungkap dalam penelitian ini. Salah satunya dinyatakan oleh informan-A1 berikut ini:

"jadi, dana aspirasi itu dikerjakan semaunya mereka (pelaksana pekerjaan dari anggaran bantuan keuangan bersifat khusus) saja... hal itu terjadi karena mudah proses pencairan anggarannya... semua desa mengeluh terkait masalah itu... jadi kalau bisa jangan lagi dimasukkan ke rekening desa anggaran seperti itu dengan pola pelaksanaan yang seperti 
itu pula... tapi untung saja tidak temuan inspektorat, karena sama sih SPJ-nya dengan SPJ kegiatan yang murni APBDesa ini... sebenarnya... ingin saya sengaja "salahkan" SPJ-nya proyek dana aspirasi ini, supaya bupati itu tahu bahwa tidak beres pekerjaan orang-orang ini (pihak yang mengerjakan)... seperti contoh ada anggaran rehabilitasi gedung PAUD, pengurus PAUD itu bersikeras mereka yang kelola dan mengerjakan... hampir saya kembalikan lagi anggaran aspirasi untuk PAUD itu ke rekening desa, karena pengurus PAUD itu tidak mau menerima usulan untuk tukang yang kami tunjuk... kami kan sudah tahu bagaimana kualitas pekerjaan dari tukang yang akan dipekerjakan oleh PAUD itu... mereka (pengurus PAUD) malah memaksa karena merasa mereka yang mengusulkan anggarannya kepada anggota dewan itu... akhirnya pusing juga saya, karena menjadi tanggungjawab saya, maka berbagai nota-nota bukti belanja yang tidak lengkap, termasuk dokumen lain untuk SPJ-nya kami yang lengkapi... kembali ke kami disini "penyakitnya" (masalahnya)" (tgl. 7/2/2017 di kantor kepala desa A1).

Memperhatikan pemicu terjadinya fraud dalam pengelolaan anggaran bantuan keuangan yang bersifat khusus dari pemerintah Kabupaten Samanta itu, maka hal itu disebabkan karena adanya tekanan dari kebijakan pemerintah yang inkonsistensi dengan regulasi yang telah ditetapkan. Penyimpangan yang terjadi telah membudaya dan menjadi kebiasaan (habbit), karena berlangsung secara simultan tanpa pernah dipersalahkan sehingga menjadi sebuah pembenaran. Maka fraud yang terjadi menjadi sebuah tindakan kesengajaan (Ernst dan Young, 2009 dalam Abdullahi \& Mansor (2015), dari pemerintah daerah yang 'dibebankan' pada pengelola keuangan desa, yang sesungguhnya mengetahui secara sadar bahwa tindakan mereka tersebut melanggar hukum, namun karena keterbatasan kemauan dan kemampuan untuk 'melawan' kebijakan dari pemerintah atasan menjadikan sebuah kenyataan, bahwa hal itu menjadi sebuah legalisasi terhadap kleptokrasi (Triyuwono et al., 2016) yang berlangsung dalam pengelolaan keuangan desa tersebut. Terdapat 3 (tiga) jenis tekanan yang dikemukakan Cressey dalam Arles (2014) sebagai penyebab seseorang melakukan fraud, yakni tekanan finansial (financial pressures), tekanan akan kebiasaan buruk (vices pressures) dan tekanan yang berhubungan dengan pekerjaan (Work-Related Pressures). Terkait dengan tekanan yang berhubungan dengan pekerjaan (Work-Related Pressures),pada konteks desa, sedikit berbeda dengan uraian yang dikemukakan Cressey dalam Arles (2014). Terjadinya fraud akibat tekanan dalam konteks pekerjaan para pengelola keuangan desa bukan karena tidak adanya kepuasan kerja yang diperoleh, namun karena tekanan atas kebijakan yang sesungguhnya 'membingungkan' pengelola keuangan desa selaku implementor. Kesempatan yang dimiliki pengelola keuangan desa adalah peluang yang harus diambil untuk menghindari tekanan diatas. Bukan semata-mata peluang untuk karena kesempatan saja walaupun disatu sisi pengendalian internal pemerintah desa memang cukup lemah.

Rasionalisasi juga menjadi elemen penting dalam terjadinya kecurangan dalam pelaksanaan keuangan desa, karena merupakan pembenaran atas tindakannya akibat dari tekanan itu sendiri. Jika Cressey dalam Arles (2014) menjelaskan bahwa pembenaran ini bisa terjadi saat pelaku ingin membahagiakan keluarga dan orang-orang yang dicintainya, pelaku merasa berhak mendapatkan sesuatu yang lebih (posisi, gaji, promosi) karena telah lama mengabdi pada perusahaan, atau pelaku mengambil sebagian keuntungan karena perusahaan telah menghasilkan keuntungan yang besar, maka dalam konteks pengelolaan keuangan desa, pembenaran itu merupakan elemen yang dipengaruhi bahwa yang mereka lakukan agar desa itu tidak memiliki temuan dalam LHP Inspektorat. Namun, peneliti sependapat dengan Ratmono et al. (2014) dalam Arles (2014) bahwa mereka yang terlibat dalam tindak kecurangan didorong oleh interaksi antara kekuatan dalam kepribadian individu dengan lingkungan eksternal. Sehingga terjadinya kecurangan cenderung akan semakin besar apabila seseorang berada dalam tekanan situasional, ada kesempatan, dan diperkuat lagi rendahnya integritas pelaku dan lemahnya pengawasan serta pembinaan. 
Berbagai permasalahan yang terjadi dalam pengelolaan keuangan desa khususnya yang bersumber dari bantuan keuangan yang bersifat khusus menjadikan banyak pengelola keuangan desa di Kabupaten Samanta bersikap antipati terhadap anggaran tersebut. hal itu salah satunya diungkapkan oleh informan A9 berikut ini:

"kalau dari kabupaten (dana aspirasi anggota dewan di Kabupaten Samanta) kami tidak pernah menerima... tapi kalau akan seperti masalah-masalah yang dihadapi desa-desa lain yang mendapatkan anggaran itu, terutama terkait masalah dalam hal pertanggungjawabannya... kami sangat "bersyukur" bang tidak ada untuk desa kami anggaran itu" (tgl. 21/2/2017 di kediaman informan).

Berpijak pada realita dan fakta di atas, pemerintah daerah justru 'mengabaikan' dinamika yang muncul akibat kebijakan pemerintah daerah tersebut. Bupati Samanta, sebagaimana diberitakan oleh media online (suara.ntb.com, 2017), memberikan pernyataan untuk 'meluruskan' kericuhan di Kabupaten Samanta terkait pemahaman soal dana aspirasi di DPRD, beliau menyatakan "sebenarnya tak pernah ada pengolaan dana aspirasi oleh anggota DPRD, yang ada usulan program melalui anggota DPRD yang dieksekusi dan diwujudkan pemerintah", berikut kutipan pernyataannya:

"Pelurusannya dalam pandangan saya, tidak ada yang namanya dana aspirasi, yang ada adalah aspirasi DPRD yang didengar dan diwujudkan Pemda Samanta, itu dalam bentuk program, kita minta ke DPRD itu untuk berikan program, program mana aspirasi yang harus dianggarkan sekarang, mereka berikan kepada kita, maka kita anggarkan sebesar apa yang menjadi hak mereka, ketika mereka ada dialog (dengan warga) pasti ada aspirasi rakyat, minta jembatan, perbaikan jalan, minta perbaikan rumah kumuh dan lain-lain, itu akan kita sikapi, tergantung dari apa yang menjadi serapan aspirasi mereka, paling baik sebenarnya serapan aspirasi yang dilakukan dewan itu di dihimpun dan diparipurnakan".

Dari pernyataan diatas, dimaknai bahwa Bupati Samanta tidak 'membenarkan' persepsi, asumsi atau kenyataan bahwa ada pengelolaan dana bantuan keuangan yang bersifat khusus oleh anggota DPRD. Menjadi benar pernyataan tersebut jika indikatornya adalah 'kehadiran' si anggota legislatif di lokasi proyek dimaksud, karena kenyataannya memang tidak pernah ada anggota DPRD yang mengelola proyek dana aspirasi secara langsung, karena yang 'mengelola' adalah orang suruhan dari 'pemilik' dana aspirasi itu (menurut pernyataan informan dan berdasarkan pengamatan peneliti sendiri). Pernyataan bupati yang menyebutkan bahwa pengelolaan anggaran (bantuan keuangan khusus) itu ditangani oleh pemerintah daerah, memang benar adanya karena pemerintah daerah kemudian mendistribusikan anggaran bantuan khusus tersebut tiap desa yang sudah ditentukan lokasinya oleh si 'pemilik' anggaran. Pemerintah desa selanjutnya menerima anggaran 'titipan' tersebut, dan diterima sebagai free-rider dalam APBDesa (karena tidak dapat diperhitungkan sebagai dasar perhitungan siltap dan tunjangan) namun akan dipertanggungjawabkan oleh sang kepala desa sebagaimana pendapatan desa lainnya. Pemerintah Kabupaten Samanta semestinya mengaplikasikan berbagai dimensi akuntabilitas, sebagaimana dinyatakan Wicaksono (2015), selain dengan memperhatikan respon yang sangat dinamis di tengah masyarakat desa, juga diperlukan kepekaan pemerintah daerah terhadap akan untuk peningkatan kinerja secara optimal, sehingga pemerintah daerah dapat mempertanggungjawabkan hasil kerja mereka kepada publik. Hal itu dapat dijadikan pijakan bagi pemerintah daerah, agar pengelolaan dana bantuan khusus tersebut dapat diketahui secara jelas oleh publik, mulai dari input, proccess, output, impact, serta outcome dari kebijakan tersebut.

Kebijakan pemerintah yang diatur dalam Pasal 98 PP No. 47/2015, pada kenyataannya dilakukan bukan "dalam rangka percepatan pembangunan desa dan pemberdayaan masyarakat" namun lebih pada sebuah anggaran 'titipan' rekan-rekan anggota legislatif di daerah yang dikemas sebagai aspirasi masyarakat. Sebelum implementasi UU No. 6/2014, anggaran tersebut 'menempel' pada Dokumen Pelaksanaan Anggaran (DPA) SKPD tertentu. Akhirnya, dengan terimplementasinya UU desa itu maka 'parasit' yang menempel di DPA SKPD berpindah pada 
APBDesa. Disatu sisi, diakui oleh para informan bahwa anggaran tersebut cukup membantu jumlah pekerjaan fisik yang bisa ditangani dalam satu tahun anggaran, namun jika dikaitkan dengan tujuan untuk memberdayakan masyarakat sebagaimana dinyatakan dalam pasal 98 PP No. 47/2015 tersebut, namun yang diberdayakan dari anggaran tersebut adalah orang-orang terdekat atau tim sukses dari 'pemilik' dana aspirasi tersebut, bukan implementasi dari konsep pemberdayaan masyarakat desa yang dimaksudkan dan diamanatkan oleh pasal 98 PP No. 47/2015 tersebut.

Pemerintah harus diberikan apresiasi dengan mengimplementasikan UU No. 6/2014. Regulasi tersebut menjadi semangat baru dalam rangka membangun desa oleh masyarakat desa sendiri. Namun berbagai kelemahan dari regulasi itu sendiri, ditambah lagi adanya kelemahan pemerintah daerah dalam memahami materi regulasi itu memunculkan persoalan baru yang tidak teridentifikasi sebelumnya. Hal itu menjadikan regulasi turunan yang ditetapkan pada skala daerah menjadi hanya pemenuhan amanat regulasi yang lebih tinggi saja, namun belum 'menjawab' persoalan sesungguhnya yang dihadapi pengelola keuangan desa. Persoalan itu semakin 'menggunung' ketika aparatur pelaksana pada instansi pemerintah yang terkait dengan pembinaan dan pengawasan tidak sepenuhnya memahami sehingga menjadikan transformasi informasi dalam bentuk instruksi, arahan, menjadi pembenaran yang 'membiaskan' masalah dari konteks sesungguhnya.

Regulasi yang ditetapkan pemerintah melalui Permendagri No. 113/2014 dan Perbup Samanta No. 12/2015 tidak sepenuhnya dapat diimplementasikan dengan baik. Karena materi dari regulasi itu sendiri masih memiliki banyak kelemahan dan justru menimbulkan berbagai penyimpangan. Sebuah ungkapan dalam Sutoro (2015) yang berbunyi:

"Peraturan bukan segala-galanya, tetapi segala sesuatunya membutuhkan peraturan.

Peraturan yang baik tidak serta merta melahirkan kebaikan dalam waktu cepat, tetapi

peraturan yang buruk dengan cepat menghasilkan keburukan".

Idiom di atas menjadi ungkapan yang menjadi fakta saat ini dan sejalan dengan MacKenzie, Garavan, \& Carbery (2011) yang menyatakan bahwa adanya aturan tidak menjamin dysfunctional behavior akan hilang atau berkurang. Selain itu, Ely (2009) juga mengungkapkan bahwa krisis keuangan yang pernah dialami Amerika Serikat disebabkan terbitnya sebuah regulasi yang justru menimbulkan keterpurukan ekonomi. Maka, peneliti sepakat dengan MacKenzie, Garavan, \& Carbery (2011) yang menyatakan bahwa dalam kegagalan organisasi dalam pengelolaan keuangan harus segera ditangani dengan aturan yang lebih baik.

Permendagri No. 113/2014 diharapkan menjadi pedoman untuk mengeliminirpeluang terjadinyapenyimpangan dalam pengelolaan keuangan desa. Namun berbagai diskresi, baik regulasi maupun kekuasaan pemerintah justru berbagai perilaku oportunis. Artinya ada kelemahan regulasi yang dimanfaatkan untuk kepentingan oknum tertentu. Hal ini sejalan dengan pendapat Yilmaz, Özer, \& Günlük (2014) yang menyatakan bahwa politik dan komitmen budgetactors mempengaruhi output prnganggaran. Maka dibutuhkan dalam pengendalian anggaran yang ketatmelaluiregulasi,akanmemberikandampaknegatifbagikinerjadan kontrol anggaran yang ketat tidak efektif pada kinerja. Namunmerujuk pada pendapat Özer \& Yilmaz (2011), maka optimalisasipengendalian pengelolaan anggaran harus melaluiregulasi yang lebih tepat untuk meminimalisir terjadinya berbagai penyimpangan dalam pelaksanaan pengelolaan keuangan desa. Nordiawan \& Hertianti (2010) menyatakan bahwa seluruh organisasi sektor publik (termasuk desa) harus memiliki regulasi yang jelas karena mengelola dana publik yang mempengaruhi hajat hidup orang banyak. Regulasi yang dimaksudkan adalah sebuah regulasi yang bersifat detail sesuai karakteristik yang dimiliki organisasi sektor publik tersebut. Namun dari berbagai standar akuntansi sektor publik yang ada saat ini belum ada yang mengatur secara khusus terkait akuntansi desa yang benar-benar lengkap dan jelas. 


\section{SIMPULAN DAN SARAN}

Berdasarkan analisis dan pembahasan diatas, terjadinya dysfunctional behavior dalam pengelolaan keuangan desa khususnya pada pengelolaan anggaran yang bersumber dari bantuan keuangan pemerintah kabupaten yang bersifat khusus, disebabkan adanya inkonsistensi dari pemerintah daerah memalui berbagai kebijakan yang di implementasikan. Kebijakan yang tidak sesuai dengan regulasi terkait dan tidak sesuai dengan karakteristik implementor menjadikan pengelola keuangan desa melakukan berbagai pensiasatan yang kemudian menjadi sebuah tindakan penyimpangan dan mengarah pada terjadinya fraud.

Bentuk kebijakan Pemerintah Kabupaten Samanta terhadap pengelolaan bantuan keuangan yang bersifat khusus dalam APBDesa, menunjukkan pemerintah daerah menggunakan diskresi atas kekuasaan yang dimilikinya terhadap pemerintah desa. Munculnya berbagai dinamika, pro kontra terhadap kebijakan itu, menunjukkan bahwa kebijakan tersebut tidak sesuai dengan amanat dari regulasi dan tidak sejalan dengan kepentingan implementor. Maka, pemerintah daerah sebagai regulator harus menyusun materi dan strategi yang baik dan tepat agar kebijakan yang dibuat bisa diimplementasi dengan baik oleh implementornya. Selain itu, pemerintah harus menjaga konsistensinya dalam memenuhi tujuan atau amanat yang dituangkan dalam regulasi tersebut.Dengan demikian diharapkan implementasi kebijakan melalui sebuah regulasi yang tepat dapat menjadi pengendali. Namun, hal ini akan bisa tercapai jika regulasi tersebut benar-benar sesuai dengan karakteristik para implementornya.

Terkait temuan dalam penelitian ini, adanya berbagai keterbatasan menjadikan perlu dilakukan pengkajian yang lebih mendalam dalam perspektif yang berbeda. Regulasi yang sudah ditetapkan sebagai bentuk kebijakan pemerintah telah di 'interpretasi' oleh pemerintah Kabupaten Samanta, namun dalam implementasinya justru tidak menunjukkan proses, tujuan serta amanat yang sesungguhnya. Hal ini dapat menjadi suatu pertimbangan peneliti selanjutnya untuk menggali informasi dari perspektif pemerintah daerah.

\section{DAFTAR RUJUKAN}

Abdullah, S., \& Asmara, J. A. (2006). Perilaku oportunistik legislatif dalam penganggaran daerah. In Simposium Nasional Akuntansi 9 Padang (pp. 23-26). Padang.

Abdullahi, R., \& Mansor, N. (2015). Fraud Triangle Theory and Fraud Diamond Theory. Understanding the Convergent and Divergent For Future Research. International Journal of Academic Research in Accounting, Finance and Management Sciences, 5(4), 38-45. https://doi.org/10.6007/IJARAFMS/v5-3/1823

Alemu, D. S. (2016). Dysfunctional Organization: The Leadership Factor. Open Journal of Leadership, 5(March), 1-7. https://doi.org/http://dx.doi.org/10.4236/oj1.2016.51001

Arles, L. (2014). Faktor - Faktor Pendorong Terjadinya Fraud: Predator vs. Accidental Fraudster Diamond theory Refleksi Teori Fraud Triangle (Klasik) Suatu Kajian Teoritis.

Bagire, V., \& Namada, J. M. (2013). Managerial Skills , Financial Capability and Strategic Planning in Organizations. American Journal of Industrial and Business Management, 3(September), 480-487. https://doi.org/http://dx.doi.org/10.4236/ajibm.2013.35055

Cole, M. S., Bruch, H., \& Walter, F. (2008). Affective Mechanisms Linking Dysfunctional Behavior to Performance in Work Teams: A Moderated Mediation Study. Journal of Applied Psychology, 93(5), 945-958. https://doi.org/10.1037/0021-9010.93.5.945

Creswell, J. W. (2015). Penelitian Kualitatif \& Desain Riset, Memilih di antara Lima Pendekatan. (S. Z. Qudsy, Ed.) (Indonesia). Yogyakarta: Pustaka Pelajar.

Creswell, J. W. (2016). Research Design: Pendekatan Metode Kualitatif, Kuantitatif dan Campuran. (H. E. Rais \& Priyati, Eds.) (Keempat). Yogyakarta: Pustaka Pelajar.

Danish, R. Q., Munir, Y., Kausar, A., \& Jabbar, M. (2014). Impact of Change , Culture and Organizational Politics on Organizational Learning. Review of Contemporary Business Research, 3(1), 115-126. 
Darumurti, K. D. (2012). Kekuasaan Diskresi Pemerintah (Pertama). Bandung: Citra Aditya Bakti.

Dunn, W. N. (2000). Pengantar Analisis Kebijakan Publik (Kedua). Yogyakarta: Gadjah Mada University Press.

Efferin, S. (2015). Akuntansi,Spirituaitas, dan Kerarifan Lokal: Beberapa Agenda Penelitian Kritis. Jurnal Akuntansi Multi Paradigma, 6(3), 466-480. https://doi.org/10.18202/jamal.2015.12.6037

Ely, B. (2009). Bad Rules Produce Bad Outcomes : Underlying Public-Policy Causes of the U . S . Financial Crisis Interactions between Finance and Human Nature. Cato Journal, 29(1), 93114.

Etienne, J. (2010, January). The Impact of Regulatory Policy on Individual Behaviour: A Goal Framing Theory Approach. Centre for Analysis of Risk and Regulation, (January), 1-26.

Fajri, R., Setyowati, E., \& Siswidiyanto. (2012). Akuntabilitas Pemerintah Desa pada Pengelolaan Alokasi Dana Desa (ADD) (Studi pada Kantor Desa Ketindan , Kecamatan Lawang , Kabupaten Malang). Jurnal Administrasi Publik, 3(7), 1099-1104.

Gamar, N., \& Djamhuri, A. (2015). Auditor Internal sebagai “ Dokter” Fraud. Jurnal Akuntansi Multi Paradigma, 6(1), 107-123. https://doi.org/10.18202/jamal.2015.04.6009

Griffin, R. W., \& Lopez, Y. P. (2005). “ Bad Behavior " in Organizations: A Review and Typology for Future Research. Journal of Management, 31(6), 988-1005. https://doi.org/10.1177/0149206305279942

Gul, Z. (2015). Impact of Employee Commitment on Organizational Development. FWU Journal of Social Sciences, 9(2), 117-124.

Guo, W., Dai, R., \& Yang, J. (2016). The Effect of Leadership Task Behavior and Relational Behavior on Job Performance: Investigating the Moderating Role of Work Alienation. Journal of Service Science and Management, 9(April), 97-110. https://doi.org/http://dx.doi.org/10.4236/jssm.2016.92013 The

Hansen, D. R., \& Mowen, M. M. (2007). Management Accounting (8th ed.). Mason, USA: Thomson Higher Education.

IAI-KSAP. (2015). Pedoman Asistensi Akuntansi Keuangan Desa. Jakarta: Ikatan Akuntan Indonesia.

Jones, M. (2005). Dysfunctional Leadership \& Organizations Workplace Politics \& Poor Performance. Executive Paper, 3(Januari), 1-6. Retrieved from www.iim-edu.org

Julianto, E. (2012). Fraud dalam Pengelolaan Keuangan Negara. In Seminar Nasional Praktik Akuntansi dalam Dunia Kerja (pp. 1-23). Yogyakarta: Universitas Atmajaya.

Kamayanti, A. (2015). Paradigma Penelitian Kualitatif dalam Riset Akuntansi: Dari Iman Menuju Praktik. In Infestasi (Vol. 11, pp. 1-10). Malang: Universitas Muhammadiyah Malang.

Kamayanti, A. (2016). Metodologi Penelitian Kualitatif Akuntansi, Pengantar Religiositas Keilmuan (Kedua). Jakarta Selatan: Yayasan Rumah Peneleh.

Ke, M., \& Shi, Y. (2014). Big Data, Big Change: In the Financial Management. Open Journal of Accounting, 3(October), 77-82. https://doi.org/http://dx.doi.org/10.4236/ojacct.2014.34009

KPK-RI. (2015). Laporan Hasil Kajian Pengelolaan Keuangan Desa: ADD dan DD. Jakarta.

Kusumastuti, N. R., \& Meiranto, W. (2012). Analisis Faktor-faktor yang Berpengaruh terhadap Perilaku Tidak Etis sebagai Variabel Intervening. Diponegoro Journal of Accounting, 1(1), 115. Retrieved from http://ejournal-s1.undip.ac.id/index.php/accounting\%0AANALISIS

Kuswarno, E. (2009). Fenomenologi (April). Bandung: Widya Padjadjaran.

Latifah, P. N. (2010). Is There of Opportunistic Behavior on the Agency Theory Aplication in the Public Sector? Fokus Ekonomi, 5(2), 85-94.

MacKenzie, C., Garavan, T. N., \& Carbery, R. (2011). Understanding and Preventing Dysfunctional Behavior in Organizations: Conceptualizing the Contribution of Human Resource Development. Human Resource Development Review, 10(4), 346-380. https://doi.org/10.1177/1534484311417549

Mardiasmo. (2009). Akuntansi Sektor Publik (Empat). Yogyakarta: Andi. 
Moleong, L. J. (2016). Metodologi Penelitian Kualitatif (Ketiga pul). Bandung: Remaja Rosdakarya.

Moustakas, C. E. (2009). Phenomenological Research Methods. Sage Publications, Inc.

Mulyono, E. (2013). Belajar Hermenutika. (N. Atho' \& A. Fahruddin, Eds.) (Kedua). Yogyakarta: IRCiSoD.

Nahruddin, Z. (2014). Akuntabilitas dan Transparansi Pengelolaan Dana Alokasi Desa di Desa Pao-Pao Kecamatan Tanete Rilau Kabupaten Barru. Otoritas, Jurnal Ilmu Pemerintahan, IV(2), 193-201.

Namada, J. M., Aosa, E., Awino, Z., \& Wainaina, G. (2014). Management Participation and Firm Performance. American Journal of Industrial and Business Management, 4(March), 113-122. https://doi.org/http://dx.doi.org/10.4236/ajibm.2014.43018

Nordiawan, D., \& Hertianti, A. (2010). Akuntansi Sektor Publik (Empat). Jakarta: Salemba Empat.

Otterlo, R. C. H. van. (2013). Does Human Resource Management Help a Company's Financial Operating Result? Journal of Service Science and Management, 6(December), 273-282. https://doi.org/http://dx.doi.org/10.4236/jssm.2013.65031 Does

Özer, G., \& Yilmaz, E. (2011). Effects of Procedural Justice Perception, Budgetary Control. Business and Economics Research Journal, 2(4), 1-18. Retrieved from www.berjournal.com

Paino, H., Ismail, Z., \& Smith, M. (2014). Modelling dysfunctional behaviour : individual factors and ethical financial decision. In Procedia - Social and Behavioral Sciences (Vol. 145, pp. 116-128). Malaysia: Elsevier B.V. https://doi.org/10.1016/j.sbspro.2014.06.018

Parsons, W. (2006). Public Policy, Pengantar Teori dan Praktik Analisis Kebijakan (Pertama). Jakarta: Kencana Prenada Media Group.

Patton, M. Q. (2002). Strategic Themes in Qualitative Inquiry. In Qualitative Research and Evaluation Methods (Third, pp. 37-73). Sage Publications, Inc.

Paudel, N. R. (2009). A Critical Account of Policy Implementation Theories: Status and Reconsideration. Nepalese Journal of Public Policy and Governance, XXV(2), 36-54. Retrieved from http://pactu.edu.np/contents/njpg/dec2009/3-narendra-paudel-a-criticalaccount-of-policy-implementation-theories.pdf

Pillay, S., \& Ron, K. (2014). An Institutional Theory Perspective on Corruption: The Case of a Developing Democracy. Financial Accountability \& Management, 30(February), 95-119.

Pradana, I. P. Y. B. (2014). Transparansi Birokrasi dalam Pengelolaan APBD di Kota Kupang. Jurnal Kebijakan \& Administrasi Publik, 18(2), 185-201.

Raghunandan, M., Ramgulam, N., \& Mohammaded, K. R. (2012). Examining the Behavioural Aspects of Budgeting with particular emphasis on Public Sector/Service Budgets. International Journal of Business and Social Science, 3(14), 110-117. Retrieved from www.ijbssnet.com

Razak, A., Unti, L., Eko, G., \& Ermanu, T. (2011). Perilaku Kuasa Eksekutif \& Legislatif dalam Penganggaran Pemda, Perspektif Interaksi Simbiolik. Jurnal Akuntansi Multi Paradigma, 2(3), 309-340.

Ricoeur, P. (2014). Teori Interpretasi. (D. Muhammed, Ed.) (Indonesia). Yogyakarta: IRCiSoD.

Santoso, A. (2007). Faktor-faktor Politik, Administrasi dan Budaya dalam Masalah Korupsi di Indonesia. Jurnal Kebijakan \& Administrasi Publik, 11(1), 87-98.

suara.ntb.com. (2017). Bupati Sumbawa luruskan pemahaman soal dana aspirasi dewan. Retrieved February 5, 2017, from http://www.suarantb.com/news/2016/09/03/7420/bupati.sumbawa.luruskan.pemahaman.soal. dana.aspirasi.dewan

Sulistyowati, R. (2013). Analisis Konsistensi Perencanaan dan Penganggaran Program Pencegahan dan Pemberantasan Tindak Pidana Pencucian Uang dan Pendanaan Terorisme di PPATK. Universitas Indonesia.

Sutoro, E. (2015). Regulasi Baru, Desa Baru: Ide, misi, dan semangat UU Desa (Pertama). Jakarta: Kementerian Desa, Pembangunan Daerah Tertinggal, dan Transmigrasi Republik Indonesia. 
Triyuwono, I., Mulawarman, A. D., Djamhuri, A., \& Prawironegoro, D. (2016). Filsafat Ilmu Akuntansi (Pertama). Jakarta: Mitra Wacana Media. Retrieved from http//www.mitrawacanamedia.com

Wicaksono, K. W. (2015). Akuntabilitas Organisasi Sektor Publik. Jurnal Kebijakan \& Administrasi Publik, 19(1), 1-16.

Wisri, \& Mughni, A. (2016). Paradigma Dasar Fenomenologis, Hermenuetika dan Teori Kritis. Jurnal Lisan Al-Hal, 8(1), 1-11. Retrieved from http://www.thedialogue.org/uploads/Remittances_and_Development/RemittanceNewsletter_ May_2011.pdf

Yılmaz, E., Özer, G., \& Günlük, M. (2014). Do Organizational Politics and Organizational Commitment Affect Budgetary Slack Creation in Public Organizations? In Procedia - Social and Behavioral Sciences (Vol. 150, pp. 241-250). https://doi.org/10.1016/j.sbspro.2014.09.047 